\title{
TRANSCENDENTAL APPERCEPTION IN THE CRITIQUE OF PURE REASON: INFLUENCE OF PREVIOUS PHILOSOPHICAL WRITINGS AND THEIR INHERITED REAPPLICATION
}

\section{APERCEPÇÃO TRANSCENDENTAL NA CRÍTICA DA RAZÃO PURA: INFLUÊNCIA DOS ESCRITOS FILOSÓFICOS ANTERIORES E A REAPLICAÇÃO DE SUA HERENÇA}

\author{
Thomas Matiolli Machado*
}

\begin{abstract}
In the Critique of Pure Reason, Kant developed new perspectives on apperception never before contemplated in the history of philosophy. However, not everything that the author of the first Critique wrote was entirely original. Indeed, Kant reapplied much that he had learned from historical philosophy, by which he was deeply influenced, creating innovative new approaches to apperception. This article aims to explain how Kant learned from the philosophers of the past in order to develop the concept of transcendental apperception in the Critique of Pure Reason.

Keywords: Critique of Pure Reason, Transcendental apperception, Abidance, Spontaneity.
\end{abstract}

\begin{abstract}
Resumo: Na Crítica da razão pura, Kant desenvolveu novas perspectivas sobre a apercepção nunca contempladas antes na história da filosofia. Mas, nem tudo o que o autor da primeira Crítica escreveu possui raízes originais. Kant reaplicou muito do que aprendeu com o passado histórico-filosófico, pelo qual foi profundamente influenciado, de um modo inovador criando novas abordagens sobre a apercepção. Este artigo tem por objetivo esclarecer como Kant aprendeu com os filósofos do passado para desenvolver o conceito de apercepção transcendental na Crítica da razão pura.

Palavras-chave: Crítica da razão pura, Apercepção transcendental, Permanência, Espontaneidade.
\end{abstract}

\section{INTRODUCTION}

The Critique of Pure Reason ${ }^{1}$ is considered one of the most important and difficult works of western philosophical literature. Although Kant's writing style might be laborious, it is usually accepted that the concepts and ideas behind his words are very clear. Even Göethe is quoted as having said that reading Kant's work "was like entering an enlightened room".

Kant was an exceptionally well-organized man and his Critique was very well planned, for the most part. Some regard the work as being somewhat divergent. Although this view does not generally seem to reflect any genuine

\footnotetext{
* Mestre e Graduado (Bacharelado) em Filosofia pela Universidade Estadual Paulista (Júlio de Mesquita Filho). 
systematic problem in the way that the work was conceived, it does seem appropriate in the case of the general concept of apperception. In comparison to most of the other central concepts in the Critique, which have complete chapters and full discussions dedicated to their analysis and implications, the notion of apperception appears to be mostly scattered throughout the book.

The pure understanding itself, concerning its possibility and the powers of cognition on which it itself rests; (...) although this exposition is of great importance in respect of my chief end, it does not belong essentially to it; because the chief question always remains: "What and how much can understanding and reason cognize free of all experience?" and not: "How is the faculty of thinking itself possible?. (CPR, Ak: Axvii).

Nonetheless, the Critique was structured in a systematic fashion. Systems are necessary to give a complete and comprehensive perspective of the various parts of any science that might mutually influence the explanation or proof of each part in particular. This treatise on the powers of the human mind and its limits was, from a historical perspective, Kant's personal work, and more importantly, a response to past eras and to the philosophical background with which he was familiar. In the particular case of apperception, Kant has to some extent agreed, but also disagreed, with the great philosophers of the past. Much of what Kant presents in the passages where he adequately treats apperception suggests this view. Furthermore, without being too unfaithful to the text, it is possible to conclude that Kant was very much inspired by previous philosophy and that some of his most notable comments on apperception were not really entirely original.

This article aims to explain how Kant learned from previous philosophers in developing the concept of transcendental apperception in the Critique of Pure Reason. The first part of the article provides a brief exposition of the state of the art concerning apperception in the seventeenth and eighteenth centuries, especially aspects with which Kant had significant contact. However, this is not true of the entire content of the concept, as it might appear at first glance. It mainly concerns two key properties of the concept, "substantiality" and "spontaneity", as being inspired by previous philosophy and crucial for the resolution of several problems that Kant had to address in the Critique of Pure Reason. The second part concerns Kant's original contribution in relation to the earlier philosophical writings. Finally, this article concludes that Kant's major achievements in the Critique, related directly or indirectly to apperception, would not have been possible without "substantiality" and "spontaneity" as key features of the mental phenomenon called "apperception". 
In the seventeenth and eighteenth centuries, the theme of apperception received a very different kind of attention to that it receives nowadays. Currently, there are entire philosophical disciplines, such as Philosophy of Mind, Panpsychism, and Ecological Philosophy, to name some of the most important, which deal with the subject. At around the time of Kant, there was no debate centered on the theme, although, as Van Robert Gulick notes:

\footnotetext{
By the beginning of the early modern era in the seventeenth century, consciousness had come full center in thinking about the mind. Indeed from the mid-17th through the late 19th century, consciousness was widely regarded as essential or definitive of the mental. (GULICK, 2014)
}

This is true in a very specific way. Much of the treatment that apperception received was to support other major themes at the time, such as the mind-body problem, indivisibility and immortality of the soul, self-knowledge, and introspection, to name a few. This makes it hard for us to find, among the classical philosophy texts that Kant read, a single systematically logical and well-formed treatise that might have inspired him to draw his own conclusions about apperception. Fortunately, it is possible to describe some of the approaches to apperception by several of the most distinctive philosophers Kant knew. The list of philosophers who inspired the writing of the Critique is long, though. To narrow it down to the subject of apperception, the most important are Leibniz, Descartes, Locke, and Hume.

Leibniz was the first to provide a proper distinction between awareness and self-awareness, and analogously between perception and apperception. In the Discourse on Metaphysics (1686), he defined perception as the faculty of receiving impressions and apperception as the potentiality to perceive them clearly. In other words, apperception is the clear awareness of the contents of thought. ${ }^{2}$ Early on, Descartes, in his Principles of Philosophy (1640), had described the very definition of thought in the framework of apperception. In the Principles of Philosophy (1640), he wrote: "By the word 'thought' ('pensée') I understand all that of which we are conscious as operating in us" (DESCARTES, 1911).

Notwithstanding, Descartes' main purpose was not directly concerned with the topic of apperception, even if he had a special doctrine for the soul (the mind). Neither was the soul, from a purely epistemological perspective, the object of his investigations. However, surprisingly, he did not excuse himself, and nor should he have, for having unintentionally contributed to the development of the concept of apperception of other philosophers. Originally, his purpose was the defense of his ontologically driven theory of immortality. To 
that end, he seemed to have found much of what he needed for his philosophical project in the concept of substance first developed by Aristotle.

Aristotle defined substance as that which cannot be affirmed in a subject or from a subject, while only substances can remain identical to themselves during the passage of time. Descartes went even further and appropriated Aristotle's logic to explain the inner functionality and nature of the soul in terms of a simple substance. According to Aristotle's logic, any predicate or attribute assigned to a subject changes this subject into an object. Hence an object is always defined by its predicates. Once more, substances are what cannot be affirmed in a subject or from a subject. Descartes placed the soul (the mind) precisely under this restriction; the soul can only be regarded as the substratum of the ideas we have, and these ideas are only accidental modifications of this unchangeable substratum:

\begin{abstract}
The human body, inasmuch as it differs from other bodies, is composed only of a certain configuration of members and of other similar accidents, while the human mind is not similarly composed of any accidents, but is a pure substance. For although all the accidents of mind be changed, although, for instance, it think certain things, will others, perceive others, etc., despite all this it does not emerge from these changes another mind: the human body on the other hand becomes a different thing from the sole fact that the figure or form of any of its portions is found to be changed. (DESCARTES, 1911, p. 5).
\end{abstract}

By arguing that the soul is incorruptible, permanent, and simple (since it cannot be analyzed as bodies can), Descartes concluded that it should have some semantic equivalence to a substance, since it analogously shares the same features. Hence, without any apparent philological difficulties, he defined the soul as precisely a substance. However, he defined it as a type of substance: a thinking substance.

Later, Locke would disagree with this characterization of the mind. In his work An Essay Concerning Human Understanding (1688), he gave some attention to apperception, albeit a very refractory one. He undeniably considered the mental phenomenon of apperception to be essential to the personal identity, and to be integral (even if partially) to the faculty of acquiring empirical knowledge. However, he gave little room to originality and restricted his considerations about apperception to what he had learned from Descartes and Leibniz. Indeed, he forged a conception very similar to that of Descartes concerning apperception as a reflexive act of the mind:

(...) the other fountain from which experience furnisheth the understanding with ideas is, - the perception of the operations of our own mind within us, as it is employed about the ideas it has got;--which operations, when the soul comes to reflect on and consider, do furnish the understanding with another set of ideas, which could not be had from things without. And such are perception, thinking, doubting, believing, reasoning, knowing, willing, and all the different actings of our own minds; - which we 
being conscious of, and observing in ourselves, do from these receive into our understandings as distinct ideas as we do from bodies affecting our senses. This source of ideas every man has wholly in himself; and though it be not sense, as having nothing to do with external objects, yet it is very like it, and might properly enough be called internal sense (LOCKE, 1999, p. 87-8).

What is most clear though is his discontent and harsh criticism of Descartes' approach to the soul (mind), considering that experience cannot inform us of the nature of our own thinking being, because it has no corresponding idea derived from experience:

\begin{abstract}
We know certainly, by experience, that we sometimes think; and thence draw this infallible consequence,- - that there is something in us that has a power to think. But whether that substance perpetually thinks or no, we can be no further assured than experience informs us. (LOCKE, 1999, p. 91)

So that if anyone will examine himself concerning his notion of pure substance in general, he will find he has no other idea of it at all, but only a supposition of he knows not what support of such qualities which are capable of producing simple ideas in us; which qualities are commonly called accidents. If anyone should be asked, what is the subject wherein color or weight inheres, he would have nothing to say, but the solid extended parts; and if he were demanded, what is it that solidity and extension adhere in, he would not be in a much better case than the Indian before mentioned who, saying that the world was supported by a great elephant, was asked what the elephant rested on; to which his answer was-a great tortoise: but being again pressed to know what gave support to the broad-backed tortoise, replied-something, he knew not what. (LOCKE, 1999, p. 278)
\end{abstract}

Finally, Hume, in contrast to the philosophers mentioned so far, devoted an entire discussion and a full chapter to apperception in his work: An Enquiry Concerning Human Understanding (1748). In the chapter entitled "Selfidentity", Hume considered apperception not as a process particularly essential to the mind, but as an arbitrary application of the usual processes by means of which our mind functions. The same mental operations that occur when we receive impressions and relate them habitually to external objects are, by the same general process of the mind, illusorily passed to the domain of inner thoughts.

(...) we suppose the whole train of perceptions to be united by identity, a question naturally arises concerning this relation of identity; whether it be something that really binds our several perceptions together, or only associates their ideas in the imagination. That is, in other words, whether in pronouncing concerning the identity of a person, we observe some real bond among his perceptions, or only feel one among the ideas we form of them. (...) The understanding never observes any real connection among objects, and that even the union of cause and effect, when strictly examined, resolves itself into a customary association of ideas. For from thence it evidently follows, that identity is nothing really belonging to these different perceptions, and uniting them together; but is merely a quality, which we attribute to them, because of the union of their ideas in the imagination, when we reflect upon them. Now the only qualities, which can give ideas an union in the imagination, are these three relations above-mentioned. These are the uniting principles in the ideal world, and without them every distinct object is separable by the mind, and may be

Problemata: R. Intern. Fil. v. 7. n. 2 (2016), p. 225-240 ISSN 2236-8612 
separately considered, and appears not to have any more connection with any other object, than if disjoined by the greatest difference and remoteness. This, therefore, on some of these three relations of resemblance, contiguity and causation, that identity depends; and as the very essence of these relations consists in their producing an easy transition of ideas; it follows, that our notions of personal identity, proceed entirely from the smooth and uninterrupted progress of the thought along a train of connected ideas, according to the principles above-explained. (HUME, 1896, p. 137-8)

II

In the Critique of Pure Reason, apperception is one of the most complicated and obscure themes encountered in the work. And the work is itself very complex, as pointed out by Paul Guyer and Allen Wood:

\begin{abstract}
The book is complex, however, not just because of the complexity of Kant's own position, but also because he argues on several fronts against several different alternative positions represented in early modern philosophy generally and within the German Enlightenment in particular. (WOOD and GUYER, 1998, p. 3).
\end{abstract}

Although scattered throughout the work, the development of the notion of apperception was in the form of an integrated and coherent system. This holds true, even though the exposition of apperception on the Critique has connections, and hence some degree of dependence, on Kant's transcendental idealism. Although the treatment of apperception is self-sustaining, Kant often writes about apperception as the supreme condition of some of the most important faculties of the mind described by his idealism. Examples of this sort can be found when he writes about apperception as the supreme principle of the usage of understanding. He even refers to it as a condition of experience itself. Hence, apperception was also extensively used as an argumentative strategy, especially in the chapter concerning "Transcendental deduction", which relates apperception to many of the fundamental claims of Kant's transcendental idealism. In summary, his purpose was to judge the quid juris of the pure concepts of understanding discovered by his metaphysical deduction, as indicated in the passage concerning "transcendental deduction" provided at the beginning of the chapter.

Jurists, when they speak of entitlements and claims, distinguish in a legal matter between the questions about what is lawful (quid juris) and that which concerns the fact (quid facti), and since they demand proof of both, they call the first, that which is to establish the entitlement or the legal claim, the deduction. (CPR, Ak: A 84/ B 117)

Nonetheless, the description of apperception alone and its main features can be detached from Kant's idealism with little loss of its meaning. As Andrew Brook says: 
At worst, most of what he said about the mind and consciousness can be detached from his idealism. Though often viewed as a quintessentially German philosopher, Kant is said to have been one-quarter Scottish. Some philosophers (often Scottish) hold that 'Kant' is a Germanization of the Scottish name 'Candt', though many scholars now reject the idea. It is noteworthy, however, that his work on epistemology, which led him to his ideas about the mind, was a response to Hume as much as to any other philosopher. (BROOK, 2013) .

Unfortunately, apperception is considered by many commentators, if not all, to be highly obscure. Furthermore, what is minimally clear to those familiar with the history of modern philosophy is that Kant's view of the mind and apperception, or self-consciousness, was unique in many aspects, compared to his predecessors. Nonetheless, was Kant completely original in his approach to apperception in the Critique of pure reason?

Some evidence might suggest he was not. It is possible that Kant could have based his notions on previous philosophy, applying well-known traditional concepts consecrated in the history of philosophy for a new purpose distinct from those for which they were originally intended. He could have obtained inspiration from existing approaches to apperception around his time, or have developed his own view of the topic based on the two previous strategies. Karl Ameriks seems to support this view, saying that: "Kant eventually develops a fairly strong critique of claims about the soul's substantiality, and this fact may be largely responsible for the general but false impression that he wholly rejected the other rationalist claims"3. (AMERIKIS, 2000, p.26). In fact, Kant did not abandon the concept of substance in the Critique of Pure Reason, especially when he dealt with apperception. He used the explanative modus of substantiality in various manners to explain the nature and inner operations in the mental apperception process.

However, he firstly appropriated Cartesian philosophy for later use in achieving his goals. In the second book of "The Transcendental Dialectic" (Chapter 1: The Paralogisms of Pure Reason, "First Paralogism: Of Substantiality"), this strategy is very clear. In common with Descartes, Kant almost invariably considers the mind described in terms of substantiality. This holds true despite Kant's strong criticism of Descartes' general doctrine of the soul. Notably, there is remarkable alikeness between Kant's quote defining apperception as something analogous to an ontological substance and Descartes' definition of soul.

Now in all our thinking the $I$ is the subject, in which thoughts inhere only as determinations, and this I cannot be used as the determination of another thing. Thus everyone must necessarily regard Himself as a substance, but regard his thinking only as accidents of his existence and determinations of his state. (CRP, Ak: A 349).

This should not come as a surprise. Some of the conceptual features of the general notion of apperception in the Critique are a heritage from the Problemata: R. Intern. Fil. v. 7. n. 2 (2016), p. 225-240 
philosophers with whom Kant was familiar. Nonetheless, apperception defined in a conceptual framework of substantiality is something that should only be ascribed to Kant, since Descartes considered that apperception was only to be encountered in reflexive perception. The substantiality features of apperception were only incorporated by Kant with what he learned from Descartes' approach to the soul. Furthermore, he reached the conclusion that the mind explained in substantial terms, although necessary to understand the phenomenon of apperception, was not sufficient. In the end, he did not remain especially faithful to the approach of Descartes.

Nonetheless, the most important point was still valuable to him, namely the explanative mode encountered in his usage of the Aristotelian concept of substance and his insight obtained from Descartes, which could be used not to explain the (ontological) nature of the mind, as the latter intended, but rather its internal functionality. In the "Second Paralogism of Simplicity", Kant argued that the concept of substance was not a product of human reasoning, but instead part of the architectonics of the mind itself. More specifically, it referred to a strictly logical category of understanding. The concept of substance could not only be used to explain how the mind works, but would also be a condition of its innermost working processes.

\begin{abstract}
It is remarkable, however, that personality, and its presupposition, persistence, hence the substantiality of the soul, must be proved only now for the first time. For if we could presuppose these, then what would of course follow is not the continuous duration of consciousness, but rather the possibility of a continuing consciousness in an abiding subject, which is already sufficient for personality, since that does not cease at once just because its effect is perhaps interrupted for a time. This persistence, however, is not given to us through anything prior to the numerical identity of our Self, which we conclude from identical apperception, but rather is concluded for the first time from it (and, if things went rightly, we would have to conclude from this first of all the concept of substance, which is usable only empirically). (CPR, Ak: A 365)
\end{abstract}

In this regard, while Descartes derived ontological implications from his doctrine of the immortality of the soul, Kant used the assemblage of materials left by the former philosopher, correcting it and giving it what he considered the proper usage. It is noteworthy that Kant diverged to a significant degree from some aspects of the original Cartesian concept of substance. Nonetheless, there is no doubt that Kant was indeed strongly inspired by Descartes in relation to the primary features of the latter's concept of substance, namely its foundational substratum of accidental properties and its immutability through time.

If this does not immediately appear sound, he himself admitted to accepting the substantial doctrine of the soul (mind), albeit with restrictions: 
This much is certain: through the I, I always think an absolute but logical unity of the subject (simplicity), but I do not cognize the real simplicity of my subject. Just as the proposition "I am substance" signifies nothing but the pure category, of which I can make no (empirical) use in concreto, so is it permitted to me to say, "I am a simple substance (...)". (CPR, Ak: A 356).

In addition, Kant frequently emphasized apperception as being the perception of the permanence of ourselves in the mutability of inner mental states through time ${ }^{4}$. In the "Second Paralogism of Simplicity", he even described such permanence as the substantiality feature of apperception. Surprisingly, and perhaps even controversial, another striking resemblance to previous philosophy that Kant incorporated in his critical system comes from Hume.

Aside from Kant's awakening from his dogmatic slumber, attributed to Hume, the Scottish philosopher possibly inspired him in a very specific manner in the development of apperception, in the Critique of Pure Reason, as a spontaneous capability. In other words, he helped Kant to realize that apperception was a creation of the human mind, rather than something passively perceived, even if introspectively. In the Treatise of human nature (1740), Hume wrote that the subjective perceptions of the mind and its inner states do not make room for the possibility of apperception ${ }^{5}$. Even if this is true, it is delicate to attribute the notion of an active process of apperception firstly to Hume, with its subsequent use by Kant. The interpretation of this point has as its foundation that for Hume, the cognition of experience is not only received passively, with the mind also being to some degree actively responsible for empirical knowledge.

In An Enquiry Concerning Human Understanding (1748), Hume described the causal relation as an essentially mental effort and the way that the mind contributes to the understanding of the world through habit. This involved reformulating the rough traditional empirical debate about the relation between mind and experience, and granting to the mind the faculty of structuring experience as we come to know it.

(...) Every distinct perception, which enters into the composition of the mind, is a distinct existence, and is different, and distinguishable, and separable from every other perception, either contemporary or successive. But, as, notwithstanding this distinction and separability, we suppose the whole train of perceptions to be united by identity, a question naturally arises concerning this relation of identity; whether it be something that really binds our several perceptions together, or only associates their ideas in the imagination. That is, in other words, whether in pronouncing concerning the identity of a person, we observe some real bond among his perceptions, or only feel one among the ideas we form of them. This question we might easily decide, if we would recollect what has been already proved at large, that the understanding never observes any real connection among [260] objects, and that even the union of cause and effect, when strictly examined, resolves itself into a customary association of ideas. For from thence it evidently follows, that identity is

Problemata: R. Intern. Fil. v. 7. n. 2 (2016), p. 225-240

ISSN 2236-8612 
nothing really belonging to these different perceptions, and uniting them together; but is merely a quality, which we attribute to them, because of the union of their ideas in the imagination, when we reflect upon them. (HUME, 1896, p. 137).

In his work, Hume dedicated an entire chapter of the book to apperception, and in this chapter, he links the same cognitive effort of the mind to knowledge of objects with the possibility of apperception. His argument is based on the notion that apperception (or self-identity, as he puts it) cannot be apprehended.

If any impression gives rise to the idea of self, that impression must continue invariably the same, thro' the whole course of our lives; since self is supposed to exist after that manner. But there is no impression constant and invariable. Pain and pleasure, grief and joy, passions and sensations succeed each other, and never all exist at the same time. It cannot, therefore, be from any of these impressions, or from any other, that the idea of self is derived; and consequently there is no such idea. (HUME, 1806, p. 137)

Apperception is not treated as impossible, though. Craftily, he suggested that apperception is only thinkable, rather than apprehensible by the same cognitive faculties actively responsible for the objective experience of the external world.

\begin{abstract}
As to causation; we may observe, that the true idea of the human mind, is to consider it as a system of different perceptions or different existences, which are linked together by the relation of cause and effect, and mutually produce, destroy, influence, and modify each other. Our impressions give rise to their correspondent ideas; and these ideas in their turn produce other impressions. One thought chases another, and draws after it a third, by which it is expelled in its turn. In this respect, I cannot compare the soul more properly to anything than to a republic or commonwealth, in which the several members are united by the reciprocal ties of government and subordination, and give rise to other persons, who propagate the same republic in the incessant changes of its parts. And as the same individual republic may not only change its members, but also its laws and constitutions; in like manner the same person may vary his character and disposition, as well as his impressions and ideas, without losing his identity. Whatever changes he endures, his several parts are still connected by the relation of causation. And in this view our identity with regard to the passions serves to corroborate that with regard to the imagination, by the making our distant perceptions influence each other, and by giving us a present concern for our past or future pains or pleasures (HUME, 1896, p. 138).
\end{abstract}

After all, in introducing the concept of transcendental apperception, Kant was not too distant from his Scottish predecessor. Guyer says:

(...) Since, as Kant learned from Hume, there is no direct or immediate presentation of a continuing self in the content of any single representation, even the mere selfascription of the several representations which is required by this principle of apperception must be found in some sort of combination among these representations. (GUYER, 2009, p. 76). 
There is no direct record of Kant saying that Hume was the inspiration for treating transcendental apperception as a spontaneous process. It is more likely that the view of the self as a representation impossible to be intuited in inner experience originated with Hume. However, Descartes and Hume do not possess all the credits for Kant's ingenious insights on transcendental apperception in the Critique of Pure Reason. It appears that Kant also considered other modes of apperception. This might suggest that he has more to offer than what he learned from his predecessors regarding the general concept of transcendental apperception. It is not sufficiently clear, though, what he meant with these distinctions, since it seems that with the exception of empirical apperception, they constitute proper names of specific properties or features attributed to the various possible views on apperception, rather than fundamentally distinct modes of apperception.

\footnotetext{
I call it the pure apperception, in order to distinguish it from the empirical one, or also the original apperception, since it is that self-consciousness which, because it produces the representation I think, which must be able to accompany all others and $\mathrm{I}$ also call its unity the transcendental unity of self-consciousness (...). (CPR, Ak: B 132)
}

Specifically with respect to empirical apperception, Kant remained faithful to what he learned from Hume. For Kant, the introspective processes by which we become aware of, or perceive, the mind's representations do not generally bring anything new to the Humean philosopher: "to be empirically conscious of one's own perceptions, feelings, thoughts, or desires is certainly to have, generally put, a representation of other representations". (STURM AND WUNDERLICH, 2010, p. 55). For this faculty or unique ability of the mind to be self-aware of its empirical content ${ }^{6}$, Kant adopted the term inner sense:

\begin{abstract}
Wherever our representations may arise, whether through the influence of external things or as the effect of inner causes, whether they have originated a priori or empirically as appearances - as modifications of the mind they nevertheless belong to inner sense, and as such all of our cognitions are in the end subjected to the formal condition of inner sense, namely time, as that in which they must all be ordered, connected, and brought into relations. (CPR, Ak: A 98-9).
\end{abstract}

Obviously enough, Kant was highly original in conceiving the overall doctrine of apperception in the Critique, compared to his predecessors. However, the most astonishing originality was not so much to be found in the content of the general concept transcendental apperception, but rather in its application in his transcendental idealism. While the meaning of transcendental apperception can be understood almost entirely independent of Kant's idealism, its application cannot. It is in the profoundly new application, using what he learned from Hume, Descartes, Leibniz, and Wolff, that we can find some of his most important contributions to philosophy. 


\title{
III
}

It can now be seen that apperception was a central and very important concept in the Critique of Pure Reason. Kant might have been inspired by previous philosophical thought, but his use of the conceptual resources that were available at the time was unique in the history of philosophy. This particularly concerned the ability of the mind to consider itself unchangeable in mental activity and actively responsible for the organization of its inner thoughts and for much of experience in general. These two simple features of the nature of the mental phenomenon of apperception brought the most complex implications and insights to the Critique of Pure Reason. More important was that apperception, described as substance and spontaneous, enabled Kant to solve, or try to solve, a number of problems. This was his most important legacy within the context of the present discussion. A glance concerning this can be seen in Kant's treating of, e.g.

(...) the question (...) about (...) the conjunction of representationsin inner sense with the modifications of our outer sensibility, and how these may be conjoined with one another according to constant laws, so that they are connected into one experience. (CPR, Ak: A 386).

For Kant, the key to the solution was in the representation of personal identity precisely as a permanent and unchanging substratum of phenomena. This feature was present in the Cartesian concept, although Kant had an original application for it:

\begin{abstract}
The schema of substance is the persistence of the real in time, i.e., representation of the real as a substratum of empirical time-determination in general, which therefore endures while everything else changes. (Time itself does not elapse, but the existence of that which is changeable elapses in it. To time, therefore, which is itself unchangeable and lasting, there corresponds in appearance that which is unchangeable in existence, i.e., substance, and in it alone can the succession and simultaneity of appearances be determined in regard to time). (CPR, Ak: A 144/ B 184).
\end{abstract}

It is not a simple task to determine with any accuracy Descartes' contribution to Kant's work, since "transcendental apperception" is a very complex subject in the Critique. This complexity involves more than the permanent unchangeable feature of transcendental apperception, which seems to be the most noticeable evidence of inspiration by Descartes in Kant's writings concerning apperception. The possibility of objectivity in human cognition was attributed by Kant to apperception, exceeding any influence of Descartes: "(...) A unity of the subject which is otherwise unknown to us, but in whose determinations there is a thoroughgoing connection of apperception (...)". 
(CPR, Ak: A 365) In other words, he described this "connection" as a unit and this, in turn, as the condition of possibility of experience.

By definition, the concept of unity concerns an a priori formal organization of elements. Using such an approach to apperception, Kant took this a priori formal property of transcendental apperception and used it to explain how the application of organizational effort to phenomena of the external senses (pure intuition of space $^{7}$ ) allows the unity of phenomena in experience. Kant believed that such organizational unity of phenomena would only be possible by means of a priori rules. Furthermore, since a priori rules follow a certain logical form, the external senses must conform to these rules in the unity of experience. Because the external senses are precisely the actual empirical experience, apperception then allows continuous uniform internal experience, due to the application of the pure concept of substance to internal data provided by external sources, as well as the objectivity of the external experience.

Kant also used the form of judgment to derive similar conclusions, since he says that experience has a discursive structure. There are discussions in the philosophical community about which approach he originally decided to use. Despite problems of logical consistency between the approaches, its conclusions appear to have been successful, with strong explanatory power contributing to persuade the reader as well as acting to support other conclusions and provide material for new discussion.

In the Critique, this argumentative system turned out to be highly complex. For example, in the absence of an exegetical effort, which is not the main purpose of the present article, it can be said that his previous conclusion was justified, conditional on the assumption that if perceptions are objective, it is necessary that the same apperception, which is the consciousness of oneself in such representation, follows in an objective way. The representation of experience as the unchanging stage for representations (in apperception, with "l" as this stage) that are subject to determined laws only updates if the "l" is aware of itself, and is also subjected to these laws in the consciousness of phenomena that arise. Otherwise, each individual would have a unique and subjective awareness of their inner states in relation to their peers, and would never know the "world" objectively through these same states. "Some link the representation of a certain word with one thing, others with another; the unity of consciousness in what is empirical is not a necessary and universal value in relation to what is given." Therefore, he says that the same principle of the transcendental unity of apperception, as immutable and permanent, is the principle of objective perception of perceptions, always following an order and rules determined a priori. Kant calls this apperception "universal", because it is what he believed to be the "logical form of all cognition." 
Although this is not nearly enough to describe the full extent of the conclusions reached by Kant in his fundamental approach to apperception, it is possible to have an idea of how the apperception presented in the first Critique was a reapplication of what Kant learned from previous philosophical thought, providing his personal response to the earlier work.

\section{REFERENCES}

AMERICKS, Karl. Kant's Theory of Mind: An Analysis of the Paralogisms of Pure Reason, $2^{\text {nd }}$ edition. Oxford: Oxford University Press, 2000.

BROOK, Andrew. Kant's View of the Mind and Consciousness of Self. The Stanford Encyclopedia of Philosophy. Edward N. Zalta (ed.). (WEB = URL: http://plato.stanford.edu/archives/fall2013/entries/kant-mind/, 2013).

COTTINGHAM, John. Dicionário Descartes. Tradução de Helena Martins / Revisão Técnica de Ethel Alvarenga. Rio de Janeiro: Jorge Zahar, 1995.

DESCARTES, René. Meditations on first philosophy. Translated by Elizabeth S. Haldane, In: The Philosophical Works of Descartes (Cambridge University Press), 1911.

. The Principles of Philosophy. Translated by E. Haldane and G. Ross. Cambridge: Cambridge University Press.

Et al. The Routledge companion to epistemology. Edited by Sven Bernecker, Duncan Pritchard. Routledge philosophy companions, 2011.

ERTL, Wolfgang. Hume's antinomy and Kant's critical turn. British Journal for the History of Philosophy, v. 10, n. 4, pp. 617-640, 2002.

GARDNER, Sebastian. Routledge Philosophy Guidebook to Kant and the Critique of Pure Reason. First published by Routledge, New Fetter Lane: London, 1999.

GULICK, Van Robert. Consciousness. The Stanford Encyclopedia of Philosophy. (Spring 2014 edition), Edward N. Zalta (ed.), URL = http://plato.stanford.edu/archives/spr2014/entries/consciousness/ 
GUYER, Paul. A dedução transcendental das categorias. In: Kant (Org. Paul Guyer), tradução de Cassiano Terra Rodrigues. Aparecida: Ideias e Letras, 2009.

Press, 1987.

Kant and the Claims of Knowledge. Cambridge: Cambridge University

; HOSTMANN, Rolf-Peter. Idealism. The Stanford Encyclopedia of Philosophy (fall 2015 edition), Edward N. Zalta (ed.), URL = <http://plato.stanford.edu/archives/fall2015/entries/idealism/>.

HENRICH, Dieter. The proof-structure of Kant's transcendental deduction. The Review of Metaphysics, v. 22, n. 4, pp. 640-659, 1969.

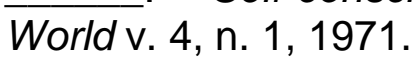

HUME, David. A treatise on human nature. Edited, with an analytical index, by L.A. Selby Bigge. Oxford: Clarendon Press, 1896.

JESUS, Paulo. "I think" as form and action: Kant's self beyond time and substance. Estudos Kantianos, Marília, v. 3, n. 2, pp. 163-180, 2015.

KANT, Immanuel. Critique of Pure Reason. Edited and translated by Paul Guyer and Allen Wood. The Cambridge edition of the works of Immanuel Kant. United Kingdom: Cambridge University Press, 1998.

KITCHER, Patricia. Kant on self-consciousness. The Philosophical Review, v. 108, n. 3, 1999.

LEIBNIZ, Gottfried Wilhelm. Discourse on Metaphysics. Translated by D. Garter and R. Aries. Indianapolis: Hackett.

LOCKE, John. An essay concerning the human understanding. The Pennsylvania State University (Electronic Classics Series), 1999.

RAUSCHER, Frederick. Kant and the demands of self-consciousness. Journal of the History of Philosophy, v. 38, n. 2, pp. 285-287, 2000.

STURM, Thomas; WUNDERLICH, Falk. Kant and the scientific study of consciousness. History of the Human Sciences, v. 23, n. 3, pp. 48-71, 2010. 
VALARIS, Markus. Inner Sense, Self-Affection and Temporal Consciousness in Kant's Critique of Pure Reason. Philosophers' Imprint, v. 8, n. 4, 2008.

\footnotetext{
${ }^{1}$ Kant's works are cited following the Akademie pagination and its edition number. Abbreviations are used to designate the Critique of pure reason as CPR.

2 Given such a definition, an approximate notion of apperception can even be found in Shakespeare's writings. Hamlet, one of his most famous protagonists, viewed the world and himself in terms of reflexive consciousness or self-awareness. 3

${ }^{4}$ Some places he discusses it within the Second Paralogism can be encountered in: CRP, Ak: A 362; A 363; A 364.

${ }^{5}$ Later on, Kant would call this special type of apperception "transcendental apperception".

6 In Jäsche Logic, the same thesis is confirmed: "Consciousness is really a representation that another representationis in me". (IX, 33)." There is no fundamental difference between the common representations of thought and the second-order (or higher order) representations, that is, representations of representations.

${ }^{7}$ See: The Transcendental Aesthetic, CPR, A 19/ B 33.
} 